\title{
PENERAPAN MODEL PEMBELAJARAN QUANTUM LEARNING UNTUK MENINGKATKAN HASIL BELAJAR SISWA KELAS VII A MTs. ALKHAIRAAT BIROMARU PADA MATERI ARITMATIKA SOSIAL
}

\author{
Lisdayanti Sultan ${ }^{1}$, Hajerina ${ }^{2}$ \\ ${ }^{1}$ Program Studi Pendidikan Matematika, FKIP. Universitas Alkhairaat \\ lisdayantisultan@yahoo.co.id \\ ${ }^{2}$ Program Studi Pendidikan Matematika, FKIP. Universitas Alkhairaat \\ Hajrinahamid@gmail.com
}

\begin{abstract}
ABSTRAK
Permasalahan yang mendasar pada penelitian ini adalah rendahnya hasil belajar siswa pada materi aritmatika sosial mengenai untung, rugi dan persentasenya serta diskon di kelas VII A MTs Alkhairaat Biromaru tahun ajaran 2017/2018. Ada beberapa penyebab rendahnya hasil belajar siswa tersebut diantaranya guru masih merupakan pusat belajar sehingga siswa masih cenderung pasif dalam pembelajaran. Ini membuat siswa menjadi tidak aktif, enggan, takut dan malu untuk bertanya. Oleh karena itu, untuk meningkatkan hasil belajar siswa kelas VII A MTs Alkhairaat Biromaru dan memaksimalkan pembelajaran maka peneliti menerapkan model Quantum Learning, yaitu suatu model pembelajaran yang seluruh proses belajarnya dapat mempertajam pemahaman dan daya ingat, serta membuat belajar sebagai suatu proses yang menyenangkan dan bermanfaat, sehingga pembelajaran menjadi lebih termotivasi. Model Quantum Learning terdiri dari 6 komponen pembelajaran yaitu : (1) Tumbuhkan, (2) Alami, (3) Namai, (4) Demonstrasikan, (5) Ulangi, (6) Rayakan. Penelitian ini merupakan penelitian tindak kelas dengan menggunakan pendekatan kualitatif yang bertujuan untuk meningkatkan hasil belajar siswa kelas VII A MTs Alkhairaat Biromaru. Subyek penelitian ini adalah seluruh siswa kelas VII A yang berjumlah 21 orang. Pada penelitian yang telah dilaksanakan, hasil penelitian ini menunjukkan bahwa aktivitas pembelajaran telah berjalan dengan baik dan mengalami peningkatan di setiap siklusnya. Hal tersebut dapat dilihat dari persentase ketuntasan belajar klasikalnya. Pada tes akhir siklus 1 mencapai rata-rata skor siswa yaitu $71,43 \%$ dengan jumlah daya serap individu 15 siswa. Kemudian pada tes akhir siklus 2 meningkat menjadi $85,71 \%$ pada kualifikasi baik. Dengan jumlah siswa yang memperoleh daya serap individu sebanyak 18 siswa.
\end{abstract}

Kata kunci: Model Quantum Learning, Hasil Belajar, Aritmatika Sosial

\begin{abstract}
The basic problem in this study is the low students learning outcomes in social arithmetic material regarding the profit, loss and percentage and discount in class VII A MTs Alkhairaat Biromaru 2017/2018 school year. There are several causes of the low students learning outcomes including teachers are still learning centers so students still tend to be passive in learning. This makes students become inactive, recultant, afraid and ashamend to ask. Therefore, to improve the learning outcomes of students of class VII A MTs Alkhairaat Biromaru and maximize learning, the researcher applied a quantum learning model, which is a learning model whose entire learning process can sharpen understanding and memory, and make learning a pleasant and useful process, so that learning becomes more motivated. The quantum learning model consists of 6 learning components, namely: 1. grow, 2. natural, 3. name, . demonstrate, 5. repeat, 6. Celebrate This research is a classroom action research using qualitative approachthat aims to improve the learning outcomes of class VII A MTs Alkhairaat Biromaru sudents. The subject of this study
\end{abstract}


were all students of class VII A totaling 21 people. In the research tht has been carried out, the result of his study indicate that learning activities have been going well and have increased in each cycle. This can be seen from the percentage of completeness of classical learning. In the final test of the first cycle reached the average score of students that is $71,43 \%$ with the amount of absorption of 15 students. Then in the final test the second cycle increased to $85,71 \%$ in good qualifications. With the number of students who get individual absorption of 18 students.

Keywords : Quantum Learning,

\section{PENDAHULUAN}

Pendidikan memiliki peranan yang sangat sentral dalam meningkatkan kualitas sumber daya manusia, karena kemajuan suatu bangsa sangat ditentukan oleh kualitas sumber daya manusianya. Oleh karena itu, pembaharuan pendidikan harus selalu dilakukan untuk meningkatkan kualitas pendidikan. Salah satu cara yang harus ditempuh untuk membentuk manusia yang berkualitas adalah melalui proses pendidikan, selain itu sekolah merupakan tempat yang sangat tepat untuk menerima pendidikan dan pembinaan sumber daya manusia yang sesuai dengan perkembangan ilmu pengetahuan dan teknologi saat ini.

Matematika sering dianggap materi pelajaran yang sulit oleh siswa, karena pelajaran matematika memerlukan pemahaman sehingga guru sebisa mungkin dapat menyampaikan materinya dengan baik. Salah satu aspek yang terkandung dalam pembelajaran matematika adalah konsep. Dahar (1998) menyebutkan, “jika diibaratkan, konsep-konsep merupakan batubatu pembangunan dalam berpikir". Akan sangat sulit bagi siswa untuk menuju ke proses pembelajaran yang lebih tinggi jika belum memahami konsep. Oleh karena itu, kemampuan pemahaman konsep adalah salah satu tujuan penting dalam pembelajaran matematika. Sebagai fasilitator di dalam pembelajaran, guru semestinya memiliki strategi agar dapat meningkatkan kemampuan serta minat siswa dalam belajar yaitu dengan menerapkan model pembelajaran, namun pada kenyataannya model pembelajaran yang sering digunakan saat ini yaitu masih berpusat pada guru itu sendiri, sehingga siswa cenderung kurang aktif dalam pembelajaran. Fenomena di atas juga dialami siswa MTs. Alkhairaat
Biromaru. Guru cenderung mengajarkan materi lalu memberi contoh, kemudian menjelaskan contoh tersebut, sehingga siswa menjadi tidak aktif, enggan, takut dan malu untuk bertanya. Siswa hanya mendengarkan semua hal yang dijelaskan oleh guru selama proses kegiatan pembelajaran, siswa tidak ikut berfikir dan menggunakan pengalaman belajarnya. Hal ini sesuai dengan hasil observasi dengan salah seorang guru matematika di MTs. Alkhairaat Biromaru pada hari Senin, 15 Januari 2018, bahwa hasil tes ulangan harian pada materi Aritmatika Sosial siswa kelas VII A yang terdaftar pada tahun 2016/2017 dengan jumlah siswa sebanyak 20 orang diperoleh ketuntasan belajar klasikal hanya sebesar 40\%. Dari hasil pekerjaan siswa dapat diketahui bahwa $60 \%$ siswa kesulitan dalam mengerjakan soal pada materi aritmatika sosial. Hal ini disebabkan karena siswa cenderung pasif saat proses pembelajaran berlangsung. Dalam upaya mengatasi permasalahan di atas, maka peneliti menggunakan salah satu model pembelajaran sebagai alternatif pemecahan masalah yang ada. Model pembelajaran merupakan salah satu komponen dalam sistem pembelajaran yang berperan dalam pencapaian tujuan pembelajaran. Joyce \& Weil (Rusman, 2010) mengatakan model pembelajaran dapat dijadikan pola pilihan, artinya para guru boleh memilih model pembelajaran yang sesuai dan efisien untuk mencapai tujuan pendidikan. Dalam hal ini, model yang digunakan oleh peneliti adalah model Quantum Learnig.

Model Quantum Learnig merupakan salah satu model pmbelajaran yang dilakukan dengan lingkungan belajar yang menyenangkan akan mampu menggabungkan rasa percaya diri, keterampilan belajar, dan keterampilan 
berkomunikasi. Setidaknya itulah yang ditawarkan Bobby DePorter dan Mike Henarcki dalam model pembelajaran temuannya. Quantum learning memberikan kiat-kiat, petunjuk, strategi, dan seluruh proses yang dapat menghemat waktu, mempertajam pemahaman dan daya ingat, dan membuat belajar menjadi suatu proses yang menyenangkan dan bermanfaat. Quantum learning merupakan gabungan yang sangat seimbang antara bekerja dan bermain, antara rangsangan internal dan eksternal. Prinsip utama model quantum learning adalah bahwa sugesti dapat dan pasti mempengaruhi hasil situasi belajar baik secara positif maupun negatif. Dengan demikian, peneliti mengharapkan dengan penggunaan model pembelajaran ini siswa dapat mengatasi kesulitan-kesulitan mereka dalam kegiatan pembelajaran seperti masalah pada materi aritmatika sosial, sehingga hasil belajar siswa dapat lebih meningkat lagi.

Sehingga berdasarkan masalah diatas, peneliti tertarik untuk melakukan penelitian yang menerapkan model pembelajaran quantum learning pada materi aritmatika sosial, melalui penelitian tindak kelas (PTK) yang berjudul Penerapan Model Pembelajaran Quantum Learning untuk Meningkatkan Hasil Belajar Siswa Kelas VII A MTs. Alkhairaat Biromaru pada Materi Aritmatika Sosial.

\section{METODE PENELITIAN}

\section{A. Rancangan Penelitian}

Penelitian ini merupakan penelitian tindakan kelas partisipan dengan menggunakan pendekatan kualitatif, karena peneliti terlibat langsung dalam proses penelitian mulai dari awal hingga akhir tindakan. Pendekatan kualitatif menghasilkan data secara tertulis maupun lisan dari aktivitas atau perilaku subyek yang diamati selama proses pembelajaran berlangsung.

Untuk kelancaran pelaksanaan penelitian ini, peneliti dibantu oleh teman sejawat mahasiswa program studi pendidikan matematika dan guru matematika Kelas VII A di MTs Alkhairaat Biromaru dalam pengumpulan data. Rancangan penelitian dalam penelitian ini terdiri dari:

\section{Desain Penelitian}

Desain penelitian ini menggunakan desain penelitian tindakan kelas (PTK) yang dikembangkan oleh Kemmis dan McTaggart yang merupakan pengembangan dari desain PTK model Kurt Lewin yang terdiri dari empat tahapan. Model penelitian tindakan kelas terdiri dari empat fase yaitu perencanaan (plan), tindakan (acting), pengamatan (observing), dan refleksi (reflect). Pada fase tindakan (acting) dan pengamatan (observing) dijadikan satu karena pelaksanaan tindakan dilaksanakan secara simultan dengan observasi, sehingga bentuknya sering dinamakan sebagai bentuk spiral.

\section{B. Setting dan Subyek Penelitian}

Penelitian ini dilaksanakan di MTs Alkhairaat Biromaru yang berlokasi di Jln. Tondei No. 21 B, Desa Mpanau, Kecamatan Sigi Biromaru, Kabupaten Sigi. Dengan subyek penelitian ini adalah seluruh siswa Kelas VII A MTs Alkhairaat Biromaru yang terdaftar pada tahun 2017/2018 yang berjumlah 21 orang siswa. Pemilihan subjek penelitian ini berdasarkan pertimbangan kesesuaian waktu materi dan juga atas arahan dari guru bidang studi matematika di sekolah yang bersangkutan.

\section{Rencana Tindakan}

Penelitian ini dilaksanakan melalui dua siklus, setiap siklus dilaksanakan sesuai dengan perubahan tingkah laku yang ingin dicapai. Untuk mengetahui kemampuan awal siswa, maka diberikan tes awal sebelum masuk siklus 1 .

Berdasarkan hasil tes awal tersebut dan informasi-informasi yang diperoleh dari guru mata pelajaran matematika dan guru wali kelas dikelas VII A, kemudian dilaksanakan tindakan pembelajaran dengan prosedur :

1. Perencanaan

2. Pelaksanaan tindakan

3. Observasi

4. Refleksi dalam setiap siklus

D. Jenis dan Teknik Pengumpulan Data

\section{Jenis Data}

Jenis data yang digunakan dalam penelitian ini adalah kualitatif yaitu informasi berbentuk kalimat yang memberi gambaran tentang ekspresi siswa berkaitan dengan tingkat pemahaman terhadap suatu mata pelajaran (kognitif), 
pandangan atau sikap siswa terhadap metode belajar yang baru, aktivitas siswa mengikuti pelajaran, perhatian, antusias dalam belajar, kepercayaan diri, motivasi belajar, dan sejenisnya yang berupa hasil observasi, catatan lapangan dan hasil wawancara. Data ini didukung oleh data kuantitatif berupa hasil tes belajar siswa yaitu (tes awal dan tes akhir untuk siklus I, dan tes akhir untuk siklus II).

2. Teknik Pengumpulan Data

Pengumpulan data dalam penelitian ini dilakukan dengan cara dan urutan sebagai berikut

a) Tes Tertulis

Tes yang digunakan dalam penelitian ini adalah tes awal dan tes akhir. Tes awal digunakan untuk mengetahui pengetahuan prasyarat siswa yang berkaitan dengan materi Aritmetika Sosial. Tes akhir tindakan dilakukan dengan tujuan untuk mengetahui kemampuan siswa dalam menyelesaikan soal-soal aritmetika sosial.

b) Wawancara

Wawancara dilakukan setelah pelaksanaan tes akhir, wawancara yang dilakukan oleh peneliti kepada informan, tujuannya untuk mengetahui informasi tentang proses pembelajaran didalam kelas pada materi Aritmatika Sosial.

c) Observasi

Observasi dilakukan pada saat proses pembelajaran di kelas berlangsung untuk mengamati aktivitas guru dan siswa selama pelaksanaan tindakan, sebagai upaya untuk mengetahui adanya kesesuaian antara perencanaan dan pelaksanaan tindakan. Observasi ini dilakukan oleh peneliti dibantu teman sejawat dan guru kelas VII A di MTs. Alkhairaat Biromaru dengan menggunakan lembar observasi.

d) Catatan Lapangan

Catatan lapangan digunakan untuk memperoleh data mengenai hal-hal yang terjadi selama proses pembelajaran berlangsung yang tidak terekam dalam lembar observasi.

\section{E. Teknik Analisis Data}

Analisis data dilakukan dengan mengacu pada model Miles Hubermen. (Wiriaatmadja,2005:70) yaitu:

\section{Mereduksi data}

Mereduksi data adalah merangkum, menyeleksi, menfokuskan, dan menyederhanakan data sejak awal pengumpulan data sampai dengan penyusunan laporan. Dalam penelitian ini data hasil wawancara, catatan lapangan direduksi sesuai dengan tujuan penelitian.

\section{Menyajikan data}

Data aktivitas siswa dalam pembelajaran dan data hasil belajar akan disajikan dalam bentuk tabel dan selanjutnya diinterpretasi dari tabel tersebut.

\section{Menyimpulkan data}

Data yang telah disajikan dianalisis dan selanjutnya menarik kesimpulan terhadap hasil analisis tersebut.

\section{F. Prosedur Penelitian}

Penelitian ini terdiri dari dua tahap, yaitu tahap pra-tindakan dan tahap pelaksanaan tindakan.

\section{Tahap Pra-tindakan}

Kegiatan yang dilakukan pada tahap ini, yaitu :

- Dengan melakukan wawancara dengan guru untuk mengetahui kesulitan yang dihadapi siswa dalam menyelesaikan soal aritmatika sosial, dan ternyata hasil belajar yang diperoleh siswa masih rendah.

- Menentukan subyek penelitian

- Menyiapkan tes identifikasi (berupa tes tertulis)

- Melaksanakan tes identifikasi

\section{Tahap Pelaksanaan Tindakan}

Kegiatan yang dilaksanakan pada tahap ini adalah mengacu pada model yang dikembangkan oleh Kemmis dan Mc Taggart yang terdiri dari 4 tahap yaitu : 1) Perencanaan, 2) Pelaksanaan tindakan, 3) Observasi, dan 4) Refleksi.

\section{Siklus I}

\section{Perencanaan}

Kegiatan yang dilakukan pada tahap ini, yaitu :

- Membuat Rencana Pelaksanaan Pembelajaran (RPP) tentang materi untung, rugi dan persentasenya dalam materi aritmatika sosial.

- Menyiapakan materi yang akan diajar

- Membuat tes awal

- Melaksanakan tes awal 
- Membuat alat evaluasi yang berupa LKS dan tes akhir

- Membuat lembar observasi aktivitas guru dan siswa.

\section{Pelaksanaan tindakan}

Kegiatan yang dilakukan pada tahap ini adalah melaksanakan pembelajaran menggunakan model pembelajaran Quantum Learning, sebagaimana yang telah direncanakan pada materi untung, rugi dan persentasenya dalam aritmatika sosial.

3. Observasi dan Evaluasi.

Pada tahap ini, melaksanakan proses pengamatan terhadap kegiatan pembelajaran di kelas dengan menggunakan lembar observasi. Kemudian melakukan evaluasi terhadap pelaksanaan pembelajaran yang telah di lakukan.

\section{Refleksi}

Kegiatan pada tahap ini adalah menganalisis data yang diperoleh berdasarkan hasil tes awal yang dilakukan sebelum pembelajaran berlangsung dan hasil tes akhir yang dilakukan sesudah tindakan pembelajaran menggunakan model pembelajaran Quantum Learning. Hasil observasi, hasil wawancara, dan hasil evaluasi dikaji dan diolah untuk menentukan langkah selanjutnya dalam upaya untuk perbaikan pada siklus berikutnya.

\section{Siklus 2}

\section{Perencanaan}

Kegiatan yang dilakukan pada tahap ini adalah mempelajari hasil refleksi pada siklus 1, yaitu bagaimana hasilnya dan apa yang harus dilakukan selanjutnya pada rencana pembelajaran. Hal ini dilakukan agar pada siklus 2 dapat terlaksana tindakan yang lebih efektif. Kegiatan yang dilakukan pada tahap ini adalah menyusun rencana pelaksanaan pembelajaran pada materi diskon, menyiapkan materi yang akan diajar, membuat LKS, menyiapkan tes akhir tindakan tentang materi diskon, dan membuat lembar observasi.

\section{Pelaksanaan tindakan}

Kegiatan yang di lakukan pada tahap ini adalah melaksanakan pembelajaran menggunakan model pembelajaran Quantum Learning, sebagaimana yang telah di rencanakan.

\section{Observasi dan Evaluasi.}

Pada tahap ini, melaksanakan proses pengamatan terhadap kegiatan pembelajaran di kelas dengan menggunakan lembar observasi. Kemudian melakukan evaluasi terhadap pelaksanaan pembelajaran yang telah di lakukan.

\section{Refleksi}

Berdasarkan hasil tes dan wawancara yang diperoleh, peneliti, guru matematika kelas VII A MTs. Alkhairaat Biromaru dan teman sejawat berdiskusi untuk mencari kelebihan dan kekurangan yang terjadi selama tindakan berlangsung.

\section{G. Kriteria Keberhasilan Tindakan}

Kriteria keberhasilan tindakan dibentuk oleh dua aspek, yaitu

1. Tindakan dianggap berhasil apabila presentase ketuntasan daya serap individu $\geq 65 \%$ dan presentase ketuntasan belajar secara klasik $\geq 75 \%$ (yang mencapai daya serap individu $\geq 65 \%$ ). Kriteria tersebut ditetapkan oleh sekolah (tempat penelitian).

Persentase daya serap secara individu $=$ $\frac{\text { skor yang dicapai }}{\text { skor maksimum soal }} \times 100 \%$

Persentase Ketuntasan Belajar Klasikal $=\frac{\text { jumlah siswa yang tuntas }}{\text { jumlah seluruh siswa }} \times 100 \%$

Depdikbud (Wardhani, 2016)

2. Hasil aktifitas guru dan siswa diperoleh dari lembar observasi yang dianalisis dan dinyatakan dalam bentuk persentase nilai rata-rata dengan rumus:

Persentase nilai rata-rata $\mathrm{NR}=$ $\frac{\text { jumlah skor }}{\text { skor maksimum }} \times 100 \%$

Pengelolaan data hasil aktivitas guru dan siswa diperoleh dari mengamati 12 aspek aktifitas guru dan siswa dengan kategori penilaian ada 5 yaitu: 
Tabel 1 . Kriteria taraf keberhasilan

\begin{tabular}{cc}
\hline Skor & Kategori \\
\hline $12 \%<\mathrm{N} \leq 21,6 \%$ & Sangat kurang \\
$21,6 \%<\mathrm{N} \leq 31,2 \%$ & Kurang \\
$31,2 \%<\mathrm{N} \leq 40,8 \%$ & Cukup \\
$40,8 \%<\mathrm{N} \leq 50,4 \%$ & Baik \\
$50,4 \%<\mathrm{N} \leq 60 \%$ & Sangat Baik \\
\hline
\end{tabular}

\section{HASIL DAN PEMBAHASAN}

\section{A. Hasil Penelitian}

Beberapa dikemukakan hasil penelitian yang terdiri dari dua bagian yaitu hasil pra tindakan dan hasil tindakan.

\section{Hasil Pra Tindakan}

Sebelum kegiatan penelitian ini dilakukan, pada tanggal 29 April 2018 peneliti menemui Kepala MTs Alkhairaat Biromaru pada pertemuan tersebut peneliti menyampaikan maksud dan tujuan peneliti yaitu meminta izin agar dapat melakukan penelitian di kelas VII A MTs Alkhairaat Biromaru. Selanjutnya Kepala MTs Alkhairaat Biromaru memberikan wewenang kepada guru mata pelajaran matematika kelas VII A untuk membantu dan bekerja sama dengan peneliti selama melakukan penelitian. Sebelum melakukan observasi di kelas VII A, peneliti melakukan wawancara dengan guru mata pelajaran matematika, yang mana dalam wawancara tersebut diperoleh informasi bahwa model pembelajaran yang diterapkan oleh guru mata pelajaran matematika adalah model pembelajaran langsung. Adapun dalam proses pembelajaran, ada beberapa siswa yang terbilang antusias dan juga ada juga siswa yang pasif, dikarenakan materi yang agak sulit dan ditambah lagi dengan jam pelajaran matematika disiang hari sehingga membuat siswa kurang bersemangat dan seringkali ribut didalam kelas.

Pada hari Senin 30 April 2018, peneliti melakukan observasi ke kelas VII A dan bertemu siswa-siswi di kelas tersebut yang didampingi oleh guru mata pelajaran matematika. Saat melakukan observasi, peneliti mengamati bagaimana situasi kelas dan menginformasikan kepada siswa bahwa peneliti akan melakukan penelitian selama 3 minggu pada mata pelajaran matematika di kelas mereka. Hasil yang diperoleh waktu observasi bahwa jam pelajaran matematika terdiri dari 4 jam pelajaran setiap minggunya dengan waktu 2 x 40 menit, yaitu 2 jam pelajaran pada hari Senin dan 2 jam pelajaran pada hari Kamis. Selain itu dari hasil observasi tersebut peneliti mengetahui bahwa siswa kelas VII A berjumlah 21 orang.

Sebelum pelaksanaan tindakan, siswa terlebih dahulu diberikan tes awal untuk mengetahui kemampuan siswa pada materi prasyarat yaitu operasi bilangan. Tes awal dilakukan pada hari Senin, 30 April 2018 yang diikuti seluruh siswa MTs Alkhairaat Biromaru kelas VII A yang berjumlah 19 orang. Tes awal diberikan soal berjumlah 5 nomor yang berkaitan dengan untung, rugi dan persentasenya serta diskon.

Setelah dilakukan tes awal, hasil pekerjaan siswa dikoreksi, untuk selanjutnya disusun dari skor tertinggi sampai terendah. Hal ini untuk mengetahui kemampuan siswa tentang materi yang diujikan.

\section{Hasil Pelaksanaan Tindakan Siklus}

Penelitian tindakan kelas yang dilaksanakan dalam dua siklus dan meliputi empat fase pada tiap siklusnya, yaitu : perencanaan, pelaksanaan tindakan, observasi, dan refleksi. Berikut uraian hasil pelaksanaan penelitian yang dicapai tiap siklus :

a. Hasil Pelaksanaan Tindakan Siklus 1

1) Hasil Tahap Perencanaan Siklus 1 kegiatan yang dilakukan pada tahap ini adalah menyiapkan seluruh perangkat pembelajaran meliputi :

a) Rencana Pelaksanaan Pembelajaran (RPP)

b) Lembar Kerja Siswa (LKS)

c) Lembar tes akhir tindakan

d) Lembar observasi aktivitas siswa dan lembar observasi aktivitas guru

2) Deskripsi Pelaksanaan Tindakan Siklus 1 Pelaksanaan tindakan tidak dilakukan oleh peneliti sendiri, oleh karena itu dalam kegiatan pembelajaran peneliti dibantu oleh satu orang teman sejawat yang bertindak sebagai pengamat siswa dan satu guru mata pelajaran 
matematika yang bertindak sebagai pengamat guru. Tindakan pembelajaran siklus 1 dilaksanakan pada hari Kamis, 3 Mei 2018 dan Senin, 7 Mei 2018 di kelas VII A MTs Alkhairaat Biromaru dengan materi untung, rugi dan persentasenya. Pelaksanaan tindakan dimulai $10.15 \mathrm{~s} / \mathrm{d}$ 11.35. Kegiatan pembelajaran dilaksanakan sesuai dengan RPP dengan menggunakan model Quantum Learning, yang terdiri dari 6 komponen pembelajaran yang disebut TANDUR, yaitu : (a) Tumbuhkan, (b) Alami, (c) Namai, (d) Demonstrasikan, (e) Ulangi, (f) Rayakan. Pembelajaran dilakukan dalam tiga tahap yaitu : (a) kegiatan awal, (b) kegiatan inti, (c) kegiatan penutup. Adapun tahap-tahap pelaksanaanya sebagai berikut :

\section{a) Kegiatan Awal}

Peneliti mengawali pembelajaran dengan mengucapkan salam dan mengajak siswa untuk berdo'a bersama sebelum proses belajar mengajar dimulai, kemudian peneliti mengabsen siswa. Pada hari itu siswa yang hadir berjumlah 21 orang siswa.

Selanjutnya peneliti mengadakan apersepsi, sebagai pengalian pengetahuan awal siswa terhadap apa yang diajarkan. Dengan mengajukan pertanyaan kepada siswa "masih ingatkah kalian tentang operasi bilangan ?", setelah itu peneliti menyampaikan tujuan pembelajaran kemudian menyampaikan model Quantum Learning yang akan dilaksanakan selama proses pembelajaran. "Assalamualaikum War.Wab, bagaimana kabar kalian hari ini? ibu harap semuanya selalu diberikan kesehatan. Sebelum kita mulai pelajaran hari ini baiknya terlebih dahulu kita berdo'a, agar pembelajaran kita hari ini mendapat keberkahan, aamiin. Baiklah pembelajaran kita hari ini yaitu menyelesaikan soal yang berkaitan dengan untung, rugi dan persentasenya.

Penyampaian diatas dilanjutkan dengan pemberian motivasi oleh peneliti kepada seluruh siswa. Peneliti menekankan bahwa materi yang sedang dipelajari sangatlah penting bagi siswa baik untuk pelajaran matematika yang lebih kompleks nantinya maupun bagi kehidupan sehari-hari. "anak-anak materi mengenai untung, rugi dan persentasenya yang akan kita pelajari hari ini sangat penting dan bermanfaat dalam kehidupan sehari-hari kita apalagi dalam hal perekonomian sebab materi ini sangat erat kaitannya dengan jual-beli, jadi ibu harap selama proses pembelajaran berlangsung sетиa memperhatikan penjelasan ibu".

b) Kegiatan Inti

Pada kegiatan inti ini, aktivitas pembelajaran yang dilakukan berdasarkan pada langkah-langkah pembelajaran yang tercantum diRPP

Pada fase pertama yaitu tumbuhkan, guru memberikan informasi mengenai model Quantum Learning kemudian guru membuat suatu kegiatan jual beli yang melibatkan siswa dengan tujuan untuk menumbuhkan minat belajar siswa sehingga siswa dapat merasa senang sebelum pembelajaran dimulai. Setelah siswa merasa senang, guru melakukan fase kedua yaitu alami, dimana guru menggali pengetahuan siswa secara kontekstual berdasarkan apa yang dialami siswa sesuai dengan materi yang diajarkan dengan memberikan beberapa pertanyaan, "setelah melihat kegiatan proses jual beli yang di praktekkan oleh ibu dan salah satu teman kalian, biasanya proses jual beli tersebut terjadi dimana? kapan si penjual dikatakan untung maupun rugi?". Setelah memberikan beberapa pertanyaan, guru kemudian melanjutkan ke fase ketiga yaitu namai, dengan mempresentasikan materi untung, rugi dan persentasenya. Kemudian memberikan contoh soal dan siswa dipersilahkan untuk maju ke depan mengerjakan soal yang diberikan, yang mana merupakan fase ke empat atau demonstrasikan.

Setelah siswa mengerjakan contoh soal, guru melanjutkan ke fase kelima atau ulangi, yaitu guru mengulangi kembali materi inti yang diberikan dan memberikan pertanyaan untuk mengetahui sejauh mana pemahaman siswa mengenai materi yang diajarkan. Kemudian guru memberikan tugas individu kepada siswa berupa Lembar 
Kerja Siswa (LKS). Setelah itu, guru mengumpulkan pekerjaan siswa.

c) Kegiatan Penutup

Pada tahap ini, guru menyimpulkan pembelajaran yang sudah dilaksanakan, selain itu guru melanjutkan ke fase ke enam atau rayakan, yang mana memberikan penghargaan kepada siswa berupa tepuk tangan atas semangat siswa dalam belajar maupun prestasi siswa dalam mengerjakan soal yang diberikan serta mendorong siswa untuk mengungkapkan kesan pentingnya pembelajaran yang baru dilaksanakan dan pengajuan saran sebagai upaya perbaikan proses pembelajaran berikutnya. Guru menutup pembelajaran dengan do'a dan salam.

3) Hasil Tes Akhir Siklus 1

Tes akhir siklus 1 dilaksanakan secara klasikal, tes ini dilaksanakan pada hari Senin, 7 Mei 2018, tes akhir siklus 1 ini dilakukan untuk mengukur sejauh mana keberhasilan tindakan yang dilakukan selama mengerjakan tes. Siswa tidak diizinkan untuk bekerja sama dengan siswa lainnya. Tes akhir pada siklus 1 ini terdiri dari 3 soal yang berbentuk uraian.

Secara keseluruhan, indikator keberhasilan yang diperoleh untuk hasil belajar belum tercapai karena presentase ketuntasan belajar secara klasikal yang diperoleh yaitu $71,43 \%$ atau sebanyak 15 orang siswa yang tuntas belajar dari 21 siswa yang mengikuti tes. Sedangkan kriteria persentase ketuntasan belajar secara klasikal yang ditetapkan oleh sekolah adalah $\geq 75 \%$.

4) Wawancara Tindakan Siklus 1

Hasil wawancara tindakan siklus 1 untuk ketiga informan adalah sebagai berikut :

Informan SA, telah menunjukkan hasil belajar yang baik terhadap materi yang diberikan dengan jawaban tes yang baik (tuntas) walaupun informan SA sering bertanya, karena informan merasa lambat dalam memahami materi yang diajarkan. Sedangkan informan PR dan AF juga telah menunjukkan hasil belajar yang cukup walaupun belum memenuhi standar kriteria keberhasilan, dikarenakan informan PR masih belum terlalu lancar dalam operasi pembagian, sedangkan informan AF memiliki kendala yaitu malu bertanya mengenai soal yang dikerjakan.

5) Hasil Observasi Tindakan Siklus 1

a) Hasil Observasi Pengamat Terhadap Aktivitas Siswa

Pada kegiatan observasi ini, pengamat terhadap aktivitas siswa yang dilakukan oleh teman sejawat yaitu Hayatun Khairun Nisa, diperoleh informasi bahwa pada umumnya subyek penelitian telah menunjukkan aktivitas yang baik dalam proses pembelajaran. Hal ini dapat dilihat dari lembar aktivitas siswa diperoleh nilai rat-rata $80 \%$ menunjukkan bahwa secara keseluruhan data aktivitas siswa dalam pembelajaran dengan menerapkan model Quantum Learning terlaksana dengan sangat baik.

b) Hasil Observasi Pengamat Terhadap Aktivitas Guru

Pada kegiatan observasi ini, pengamatan terhadap aktivitas guru dilakukan oleh guru mata pelajaran matematika ibu Rizkina, berdasarkan hasil observasi yang dilakukan pengamat kepada peneliti, bahwa pembelajaran yang dilakukan oleh peneliti dengan menggunakan model Quantum Learning mengalami peningkatan pada siklus 1 .

Berdasarkan tabel hasil dari pengamatan untuk analisis aktivitas guru diperoleh nilai rata-rata $78,18 \%$ menunjukkan bahwa secara keseluruhan peneliti mampu melaksanakan dengan baik seluruh aspek pengamatan sesusai langkah-langkah model Quantum Learning. Maka dari itu dapat dikatakan bahwa aktivitas guru dengan menggunakan model Quantum Learning terlaksana dengan baik.

6) Refleksi Siklus 1

Refleksi dilakukan untuk memenuhi kekurangan dan kelebihan yang terjadi selama siklus 1 berlangsung guna merencanakan tindakan yang efektif pada tindakan siklus 2. Pembelajaran pada siklus 1 difokuskan agar siswa dapat membiasakan diri pada penerapan model Quantum Learning dalam upaya memahami materi yang diajarkan. 
Pada akhir tindakan siklus 1, peneliti bersama dengan pengamat mendiskusikan temuan-temuan selama tindakan siklus 1. Pada saat pembelajaran dengan menerapkan model Quantum Learning berlangsung dengan baik, meskipun suasana kelas belum kondusif dan penguasaan kelas belum maksimal, pada awal pembelajaran masih ada siswa yang bermain atau kurang memperhatikan penjelasan guru dipapan tulis. Tetapi secara keseluruhan siswa senang belajar dengan menerapkan model Quantum Learning, karena berhubungan langsung dengan kehidupan nyata siswa.

Dari hasil analisis tes lembar kerja siswa pada siklus 1 diperoleh informasi bahwa indikator keberhasilan untuk hasil belajar belum tercapai, karena persentase ketuntasan belajar secara klasikal diperoleh $61,90 \%$ atau sebanyak 21 orang yang mengikuti hanya 13 siswa saja yang tuntas. Sedangkan kriteria yang ditetapkan sekolah dalam persentase ketuntasan belajar secara klasikal adalah $\geq 75 \%$, Hasil belajar subyek penelitian tersebut belum memenuhi standar ketuntasan klasikal. Dari hasil tersebut, menunjukkan bahwa target pencapaian keberhasilan pada siklus 1 belum terpenuhi. Karena kurangnya perhatian siswa dalam menerima pelajaran dan perasaan takut untuk bertanya sehingga pencapaian keberhasilan siswa belum terpenuhi. Dengan demikian, untuk mengatasi permasalahan tersebut peneliti lebih antusias lagi di kelas dalam menerapkan model Quantum Learning agar siswa lebih memperhatikan dan terlihat aktif selama proses pembelajaran berlangsung.

b. Hasil Pelaksanaan Tindakan Siklus 2

1) Hasil Tahap Perencanaan Siklus 2

Kegiatan yang dilakukan pada tahap ini seperti halnya pada siklus 1 dalah menyiapkan seluruh perangkat pembelajaran yakni :

a) Rencana Pelaksanaan Pembelajaran (RPP)

b) Lembar Kerja Siswa (LKS)

c) Lembar tes akhir tindakan

d) Lembar observasi aktivitas siswa dan lembar observasi aktivitas guru
2) Deskripsi Pelaksanaan Tindakan Siklus 2 Pelaksanaan tindakan pada tahap ini dilakukan pada hari Senin, 14 Mei 2018 dan Kamis, 17 Mei 2018 di kelas VII A MTs Alkhairaat Biromaru dengan materi aritmatika sosial mengenai diskon. Materi ini disajikan dalam waktu 2 x 40 menit dengan menggunakan model Quantum Learning. Dalam penyajian materi peneliti bertindak sebagai pengajar (guru), dan satu teman sejawat bertindak sebagai pengamat observasi aktivitas siswa. Penyajian materi dilaksanakan sesuai rencana pelaksanaan pembelajaran dengan menggunakan model Quantum Learning. Pembelajaran dilakukan dalam tiga tahap yaitu : (a) kegiatan awal, (b) kegiatan inti, (c) penutup.

$$
\text { Adapun tahap-tahap }
$$
pelaksanaannya sebagai berikut:

a) Kegiatan awal

Peneliti mengawali pembelajaran dengan mengucapkan salam dan mengajak siswa untuk berdo'a bersama sebelum proses belajar mengajar dimulai, kemudian peneliti mengabsen siswa. Pada hari itu siswa yang hadir berjumlah 21 orang siswa.

Selanjutnya peneliti mengadakan apersepsi, sebagai pengalian pengetahuan awal siswa terhadap apa yang diajarkan. Dengan mengajukan pertanyaan kepada siswa "masih ingatkah kalian tentang untung, rugi dan persentasenya ?", setelah itu peneliti menyampaikan tujuan pembelajaran kemudian menyampaikan model Quantum Learning yang akan dilaksanakan selama proses pembelajaran. "Assalamualaikum War.Wab, bagaimana kabar kalian hari ini? ibu harap semuanya selalu diberikan kesehatan. Sebelum kita mulai pelajaran hari ini baiknya terlebih dahulu kita berdo'a, agar pembelajaran kita hari ini mendapat keberkahan, aamiin. Baiklah pembelajaran kita hari ini yaitu menyelesaikan soal yang berkaitan dengan diskon.

Penyampaian diatas dilanjutkan dengan pemberian motivasi oleh peneliti kepada seluruh siswa. Peneliti menekankan bahwa materi yang sedang dipelajari sangatlah penting bagi siswa 
baik untuk pelajaran matematika yang lebih kompleks nantinya maupun bagi kehidupan sehari-hari. "anak-anak materi mengenai diskon yang akan kita pelajari hari ini sangat penting dan bermanfaat dalam kehidupan sehari-hari kita apalagi dalam hal perekonomian sebab materi ini sangat erat kaitannya dengan jual-beli sama halnya dengan materi untung dan rugi, jadi ibu harap selama proses pembelajaran berlangsung semua memperhatikan penjelasan ibu".

b) Kegiatan Inti

Pada kegiatan inti ini, aktivitas pembelajaran yang dilakukan berdasarkan pada langkah-langkah pembelajaran yang tercantum diRPP. Pada fase pertama atau tumbuhkan, guru memberikan informasi mengenai model Quantum Learning kemudian guru membuat suatu kegiatan yang berhubungan dengan proses jual beli yang melibatkan siswa dengan tujuan untuk menumbuhkan minat belajar siswa sehingga siswa dapat merasa senang sebelum pembelajaran dimulai. Setelah siswa merasa senang, guru melanjutkan ke fase kedua atau alami, yang mana guru menggali pengetahuan siswa secara kontekstual berdasarkan apa yang dialami siswa sesuai dengan materi yang diajarkan dengan memberikan beberapa pertanyaan, "setelah melihat kegiatan proses jual beli yang di praktekkan oleh ibu dan salah satu teman kalian, biasanya barang yang di diskon tersebut dapat kita temui dimana saja?" Setelah memberikan beberapa pertanyaan, guru kemudian melanjutkan ke fase ketiga yaitu namai, guru mempresentasikan materi diskon. Kemudian memberikan contoh soal dan siswa dipersilahkan untuk maju ke depan mengerjakan soal yang diberikan, yang mana merupakan fase ke empat atau demosntrasikan.

Setelah siswa mengerjakan contoh soal, guru melanjutkan ke fase kelima atau ulangi, dimana guru mengulangi kembali materi inti yang diberikan dan memberikan pertanyaan untuk mengetahui sejauh mana pemahaman siswa mengenai materi yang diajarkan. Kemudian guru memberikan tugas individu kepada siswa berupa Lembar
Kerja Siswa (LKS). Setelah itu, guru mengumpulkan pekerjaan siswa.

c) Kegiatan Penutup

Pada tahap ini, guru menyimpulkan pembelajaran yang sudah dilaksanakan, dan melanjutkan ke fase ke enam atau rayakan,yaitu guru memberikan penghargaan kepada siswa berupa tepuk tangan atas semangat siswa dalam belajar maupun prestasi siswa dalam mengerjakan soal yang diberikan serta mendorong siswa untuk mengungkapkan kesan pembelajaran. Guru menutup pembelajaran dengan do'a dan salam.

3) Hasil Tes Akhir Siklus 2

Hasil tes akhir dilaksanakan setelah kegiatan pembelajaran untuk mengetahui hasil belajar siswa. Tes akhir siklus 2 ini dilaksanakan pada hari Kamis, 17 Mei 2018 dengan jumlah soal yang diberikan sebanyak 2 butir soal dalam bentuk uraian. Berdasarkan hasil analisis tes akhir individu siklus 2 menunjukkan bahwa siswa yang tuntas belajar sebanyak 18 orang dari 21 jumlah siswa secara keseluruhan dengan presentase ketuntasan belajar klasikal sebesar $85,71 \%$. Sedangkan, kriteria persentase ketuntasan belajar secara klasikal yang ditetapkan oleh sekolah adalah $\geq 75 \%$. Dengan demikian, indikator keberhasilan yang diperoleh untuk hasil belajar siswa tercapai.

4) Wawancara Tindakan Siklus 2

Hasil wawancara tindakan siklus 2 untuk ketiga informan adalah sebagai berikut:

ketiga informan telah menunjukkan hasil belajar yang baik terhadap materi diskon dengan jawaban tes yang baik (tuntas). Selain itu, ketiganya mengungkapkan lebih mudah memahami materi yang diajarkan dikarenakan contoh soal yang diberikan mudah dipahami.

5) Hasil Observasi Siklus 2

a) Hasil Observasi Aktivitas Siswa

Berdasarkan hasil observasi ini, pengamatan terhadap aktivitas siswa yang dilakukan oleh teman sejawat yaitu Hayatun Khairun Nisa, diperoleh informasi bahwa pada umumnya subyek penelitian telah menunjukkan aktivitas yang baik dalam proses pembelajaran. Hal 
ini dapat dilihat dari lembar analisis aktivitas siswa diperoleh rata-rata $85,45 \%$ menunjukkan bahwa secara keseluruhan data aktivitas siswa dalam pembelajaran dengan menerapkan model Quantum Learning terlaksana dengan sangat baik.

b) Hasil Observasi Aktivitas Guru

Pada kegiatan observasi ini, pengamatan terhadap aktivitas guru dilakukan oleh guru mata pelajaran matematika yaitu ibu Rizkina, berdasarkan hasil observasi yang dilakukan oleh peneliti dengan menggunakan model Quantum Learning mengalami peningkatan dari siklus 1 .

Berdasarkan tabel hasil dari pengamatan untuk analisis aktivitas guru diperoleh nilai rata-rata $87,27 \%$ menunjukkan bahwa secara keseluruhan peneliti mampu melaksanakan dengan baik seluruh aspek pengamatan sesuai langkah-langkah model Quantum Learning. Maka dari itu dapat dikatakan bahwa aktivitas guru dengan menggunakan model Quantum Learning terlaksana dengan sangat baik.

6) Refleksi Siklus 2

Kegiatan pada tahap ini adalah mendiskusikan hasil-hasil yang telah dicapai dalam pelaksanaan tindakan siklus 2. Dari hasil diskusi diperoleh keaktifan siswa dalam proses pembelajaran sudah meningkat, hanya saja ketelitian dalam berhitung masih ada beberapa siswa yang perlu ditingkatkan. Selain itu, dari hasil tes akhir tindakan siklus 2 menunjukkan bahwa ketuntasan klasikal diperoleh yaitu $85,71 \%$ siswa yang tuntas sehingga dapat dinyatakan telah ada peningkatan dari siklus 1. Hasil pekerjaan siswa pada kegiatan pembelajaran dikategorikan baik dan telah mencapai tujuan pembelajaran. Dari hasil tersebut, menunjukkan bahwa target pencapaian keberhasilan tindakan telah terpenuhi.

\section{B. Pembahasan}

Berdasarkan data dan hasil penelitian yang telah dikemukakan diatas, maka selanjutnya yang akan dipaparkan adalah mengenai analisis data hasil perolehan yang ada.

Penelitian ini dimulai dari observasi yang dilakukan peneliti sebagai kegiatan pra tindakan. Observasi dilakukan disekolah yang menjadi lokasi penelitian yaitu MTs Alkhairaat Biromaru pada hari Senin, 30 April 2018. Selain melakukan observasi, dilakukan pula persiapan perangkat pembelajaran dalam penelitian. Tes yang pertama dilakukan adalah melakukan tes awal terhadap siswa untuk mengetahui pemahaman awal siswa terhadap materi yang nantinya akan berpengaruh terhadap hasil belajar mereka. Informasi yang diperoleh setelah melakukan tes awal dari 19 siswa, hanya ada 8 orang siswa yang tuntas sedangkan 11 siswa yang belum mencapai ketuntasan.

Hasil pekerjaan siswa LKS individu pada siklus 1 yang diikuti 21 siswa, diperoleh nilai yang tidak memenuhi standar ketuntasan yaitu 13 orang siswa, dengan presentase $61,90 \%$ Sedangkan hasil analisis LKS individu pada siklus 2 yang diikuti oleh 21 orang siswa mengalami peningkatan presentase sebesar $80,95 \%$.

Setelah melaksanakan tes akhir pada siklus 1 dari 21 siswa yang mengikuti tes akhir, diperoleh presentase KBK 71,43\% dimana siswa yang tidak mencapai ketuntasan hanya 6 siswa. Sedangkan pada siklus 2 mengalami peningkatan dari 21 siswa yang mengikuti tes akhir, diperoleh presentase KBK 85,71\% dimana siswa yang memenuhi standar ketuntasan siswa adalah 18 siswa dari 21 jumlah keseluruhan siswa. Hal ini menunjukkan bahwa hasil belajar siswa tentang materi aritmatika sosial mengenai untung, rugi dan persentasenya serta diskon meningkat.

Berdasarkan hasil penelitian yang dilakukan diatas, maka peneliti memperoleh gambaran bahwa model Quantum Learning juga dapat membuat siswa terlibat aktif dalam kegiatan pembelajaran dengan perubahan dari berbagai bidang mulai dari lingkungan belajar yaitu kelas, materi pembelajaran yang menyenangkan, penumbuhan rasa percaya diri, serta mengefisienkan waktu pembelajaran.

Keberhasilan pembelajaran dengan model Quantum Learning mempunyai 6 komponen yang disebut dengan TANDUR yaitu: (1) Tumbuhkan, (2) Alami, (3) Namai, (4) Demonstrasikan, (5) Ulangi, (6) Rayakan. Selain itu, berhasilnya tindakan pembelajaran 
juga didukung oleh sarana pembelajaran yang cukup memadai dan sangat membantu siswa. Bahan pembelajaran berupa berkas materi pembelajaran yang menjadi pegangan siswa merupakan rangkuman sistematis dari penjelasan guru, sebab dengan adanya buku pegangan tersebut siswa dapat memfokuskan konsentrasinya pada penjelasan guru dan lebih menghemat waktu untuk mencatat.

Dalam penerapan model pembelajaran yang digunakan, menurut guru mata pelajaran matematika dalam wawancaranya bersama peneliti bahwa model Quantum Learning sangat memudahkan guru dalam meningkatkan hasil belajar siswa terhadap pelajaran matematika, karena dalam proses pembelajarannya banyak melibatkan siswa mulai dari pemberian contoh, hingga melatih rasa percaya diri siswa untuk mengekspresikan pengalaman belajarnya sehingga siswa lebih aktif.

\section{KESIMPULAN}

Berdasarkan hasil penelitian dan pembahasan, maka dapat disimpulkan beberapa hal sebagai berikut:

1. Dengan menerapkan model Quantum Learning pada materi aritmatika sosial dapat meningkatkan hasil belajar siswa kelas VII A MTs Alkhairaat Biromaru melalui 6 komponen pembelajaran model Quantum Learning yaitu, tumbuhkan, alami, namai, demonstrasikan, dan rayakan.

2. Pembelajaran matematika dengan menggunakan model Quantum Learning pada materi aritmatika sosial menunjukkan suatu peningkatan yang membantu siswa terlibat aktif dalam proses pembelajaran yang dapat menumbuhkan rasa percaya diri siswa. Selain itu, hal ini terjadi karena model Quantum Learning merupakan model yang seluruh proses belajarnya dapat mempertajam pemahaman dan daya ingat, serta membuat belajar sebagai suatu proses yang menyenangkan dan bermanfaat, sehingga pembelajaran menjadi lebih termotivasi.

3. Hasil belajar siswa yang meningkat dilihat dari tes akhir siklus 1 yang mencapai skor rat-rata $71,43 \%$ dan siklus 2 mencapai skor rata-rata $85,71 \%$. Ini adalah bukti keberhasilan pembelajaran Matematika dikelas VII A MTs Alkhairaat Biromaru dengan model Quantum Learning, sudah mencapai KKM yang ditetapkan sebesar 65, dengan kata lain model Quantum Learning, dapat meningkatkan hasil belajar siswa.

\section{SARAN}

Berdasarkan kesimpulan penelitian ini, maka peneliti mengajukan saran-saran sebagai berikut:

1. Dalam proses pembelajaran, seorang guru hendaknya memahami materi yang diajarkan dan guru diharapkan mempersiapkan rencana pembelajaran yang baik.

2. Untuk meningkatkan hasil belajar siswa hendaknya menggunakan model atau metode yang sesuai denagn bahan ajar sehingga, dapat menciptakan suasana proses belajar mengajar yang menyenangkan agar hasil belajar dapat memenuhi Kriteria Ketuntusan Minimal (KKM).

3. Siswa diharapkan untuk lebih aktif dalam proses pembelajaran baik pembelajaran baik pembelajaran model Quantum Learning maupun model pembelajaran lain.

\section{DAFTAR PUSTAKA}

Buchori, dkk. (2005). Jenius Matematika untuk SMP/MTs Kelas VII. Semarang : CV. Aneka Ilmu.

Cahyo, A. (2013). Panduan Aplikasi TeoriTeori Belajar Mengajar. Jogjakarta: DIVA Press.

Dahar, R.W. (1998). Teori-Teori Belajar. Jakarta : Erlangga. (2006). Teori-Teori Belajar \& Pembelajaran. Bandung : Erlangga.

DePorter, B \& Hernacki, M. (2015). Quantum Learning Membiasakan Belajar Nyaman dan Menyenangkan. Bandung: Kaifa.

DePorter, B dkk. (2010). Quantum Teaching Mempraktikkan Quantum learning Di Ruang-ruang Kelas. Bandung: Kaifa. 
Hasbullah. (2005). Dasar-dasar Ilmu Pendidikan, Jakarta : PT. Raja Grafindo Persada.

Jaeng, Maxinus. (2009). Belajar dan Pembelajaran Matematika. Palu: FKIP Universitas Tadulako

Pringgwidagda, S. (2002). Strategi Penguasaan Bahasa. Yogyakarta: Adicita Karya Nusa.

Purwanto, N. (2011). Psikologi Pendidikan. Bandung: PT Remaja Rosdakarya.

Rusman. 2010. Model-model Pembelajaran Mengembangkan Profesionalisme Guru. Jakarta: PT. Raja Grafindo Persada.

Suprijono. (2009). Cooperative Learning: Teori dan Aplikasi PIKEM. Jogjakarta: Pelajar.

Tampubolon, S. (2013). Penelitian Tindakan Kelas. Jakarta : Erlangga.

Thobroni \& Mustofa. (2011). Belajar \& Pembelajaran Pengembangan Wacana Dan Praktik Pembelajaran dalam Pembangunan Nasional. Yogyakarta: Ar-Ruzz Media.

Thobroni, M. (2015). Belajar dan Pembelajaran: Teori dan Praktik. Yogyakarta: Ar-Ruzz Media.

Wardhani,K.I. (2016). Penerapan Pendekatan Contextual Teaching and Learning (CTL) Untuk Meningkatkan Hasil Belajar Siswa Kelas VIII E SMPN 18 Sigi Pada Materi Sistem Persamaan Linear Dua Variabel (SPLDV). Skripsi tidak diterbitkan. FKIP, Universitas Alkhairaat Palu. 
Lisdayanti Sultan, Hajerina 